УДК 37.011.2:316.614-053.6:061.2]:37-047.44

DOI https://doi.org/10.32782/humanitas/2021.4.10

\title{
Вікторія ШТИк
}

аспірантка кафедри соціальної роботи та педагогіки вищої школи, Волинський національний університет імені Лесі Украӥнки, просп. Волі, 13, м. Луцьк, Україна, 43025

ORCID: 0000-0002-9087-5980

Бібліографічний опис статті: Штик, В. (2021). Діагностичний інструментарій для визначення рівня сформованості соціальної компетентності молоді в діяльності громадських організацій. Ввічливість. Humanitas, 4, 64-69, doi: https://doi.org/10.32782/humanitas/2021.4.10

\section{ДІАГНОСТИЧНИЙ ІНСТРУМЕНТАРІЙ ДЛЯ ВИЗНАЧЕННЯ РІВНЯ СФОРМОВАНОСТІ СОЦАЛЬНОЇ КОМПЕТЕНТНОСТІ МОЛОДІ В ДІЯЛЬНОСТІ ГРОМАДСЬКИХ ОРГАНІЗАЦІЙ}

\begin{abstract}
У статті розглянуто проблему формування та діагностики соизільної компетентності молоді в діяльності громадських організацій. Проаналізовано наукові підходи до структурних компонентів та показників соціальної компетентності й обтрунтовано показники сформованості соиіальної компетентності молоді в діяльності громадських організацій. Розкрито критерії соціальної компетентності: мотиваційно-особистісний, когнітивно-иіннісний, комунікативний, діяльнісний. Представлено соціальну компетентність, яка охоплює професійну, навчальну, громадську, особистісну сфери життєдіяльності людини. 3'ясовано, щчо соціальна компетентність $\epsilon$ найважливішою для встановлення соиіальних контактів, розуміння суті міжособистісної взаємодії. Запропоновано комплекс діагностичних методик для визначення рівня соціальної компетентності молоді в діяльності громадських організаиій. Обгрунтовано дочільність представлених методик вивчення рівня сформованості соиіальної компетентності. 3'ясовано, щзо методики дозволять дослідити навички критичного мислення, креативності, комунікативно-особистісний потенціал, рівень управління своїми емоціями, потребу в спілкуванні, самооиінку, емпатійні навички, мотив досягнення успіху, здатність до критичного аналізу інформації, технік переконання, відволікання уваги тощь. Представлено короткий опис методик, як-от «Вимірювання комунікативної й соиіальної компетентності» КОСКОМ В.М. Куніичиоӧ, «Адаптований тест критичного мислення» Л. Старкі, опитувальник Ю.М. Орлова «Потреба в спілкуванні», «Тест емочійного інтелекту EQ» Н. Холла, опитувальник М. Шерер та Дж. Маддукс «Шкала самоефективності», «Діагностика особистісної креативності» Є. Тунік, опитувальник А. Реана «Мотивація успіху та страх невдачі», "Діагностика оиінки самоконтролю в спілкуванні» М. Снайдера, «Діагностика рівня емпатії» I. Юсупова.

Ключові слова: сочіальна компетентність, молодь, громадська організація, методика, діагностичний інструментарій.
\end{abstract}

\section{Viktoriia SHTYK}

Postgraduate Student at the Department of Social Pedagogy and Pedagogy of Higher School, Lesya Ukrainka Volyn National University, 13, Voli Avenue, Lutsk, Ukraine, 43025

ORCID: 0000-0002-9087-5980

To cite this article: Shtyk, V. (2021) Diahnostychnyy instrumentariy dlya vyznachennya rivnya sformovanosti sotsialnoyi kompetentnosti molodi v diyalnosti hromadskykh orhanizatsiy. [Diagnostic tools for determining the level of formation of social competence of youth in the activities of non-governmental organizations]. Vvichlyvist. Humanitas, 4, 64-69, doi: https://doi.org/10.32782/humanitas/2021.4.10

\section{DIAGNOSTIC TOOLS FOR DETERMINING THE LEVEL OF FORMATION OF SOCIAL COMPETENCE OF YOUTH IN THE ACTIVITIES OF NON-GOVERNMENTAL ORGANIZATIONS}

The article considers the problem of formation and diagnosis of social competence of youth in the activities of public organizations. The scientific approaches to the structural components and indicators of social competence are analyzed and the indicators of the formation of social competence of young people in the activities of public organizations are substantiated. Criteria of social competence are revealed: motivational-personal, cognitive-value, communicative, activity. 
The social competence which covers professional, educational, public, personal spheres of human life is presented. It was found that social competence is the most important for establishing social contacts, understanding the essence of interpersonal interaction. A set of diagnostic methods for determining the level of social competence of young people in the activities of public organizations is proposed. The expediency of the presented methods of studying the level of formation of social competence is substantiated. It was found that the methods will explore the skills of critical thinking, creativity, communication and personal potential, the level of management of their emotions, the need for communication, self-esteem, empathic skills, motivation to succeed, the ability to critically analyze information, persuasion techniques, distractions and more. A brief description of techniques such as: "Measurement of communicative and social competence" by KOSKOM V. M. Kunitsyna, "Adapted test of critical thinking” by L. Starki, questionnaire by Y.M. Orlov "Need for communication", "Test of emotional intelligence EQ" by N. Hall, questionnaire by M. Scherer and G. Maddux "Scale of self-efficacy", "Diagnosis of personal creativity" E. Tunic, questionnaire A. Rean "Motivation for success and fear of failure", "Diagnosis of self-control in communication" by M. Snyder, "Diagnosis of the level of empathy” by I. Yusupova.

Key words: social competence, youth, non-governmental organizations, methods, diagnostic tools.

Постановка наукової проблеми та її значення. У сучасних умовах розвитку людського суспільства зростає роль молодих людей у процесах державотворення, участі в діяльності інститутів громадянського суспільства, громадських організацій, роль молоді у формуванні суспільної думки та громадянського суспільства загалом. Сучасна соціально-компетентна молода людина має вміти критично мислити, швидко адаптуватися до нових умов, продукувати нові ідеї, успішно комунікувати з іншими, виявляти творчість у професійній діяльності, швидко переключатися на інші види діяльності, тому постає завдання пошуку шляхів, які дозволяють дослідити рівень сформованості соціальної компетентності молоді.

World Economic Forum (Всесвітній економічний форум) опублікував звіт «Майбутнє робочих місць - 2020», експерти якого прогнозують, що роботодавці до 2025 року поділять роботу між людьми й автоматизованими системами. Також у звіті зроблено прогноз навичок, які будуть затребувані у 2025 році, як-от: аналітичне мислення та інновації; активне навчання та навчальні стратегії; комплексне вирішення проблем; критичне мислення та аналіз; креативність, оригінальність та ініціативність; лідерство та соціальний вплив; використання технологій, моніторинг і контроль; дизайн технологій та програмування; стресостійкість та гнучкість; уміння аргументувати погляди, вирішувати проблеми та генерувати ідеї (World Economic Forum, 2020).

Уперше 3'являються такі навички, як активне навчання (active learning), витривалість (resilience), стресостійкість (stress tolerance) та гнучкість (flexibility).

Отже, існує об'єктивна потреба в розробці сучасних технологій формування соціальної компетентності молоді, яка готова до діяль- ності в умовах змін. Це й зумовило необхідність пошуку відповідного діагностичного комплексу.

Аналіз останніх досліджень і публікацій. У практиці закордонних науковців знаходимо розроблені та апробовані методики для вимірювання компонентів соціальної компетентності (S. Han, K. Kemple, 2006), дослідження рівня емоційної та соціальної компетентності (V. Arghode, 2013), соціальна компетентність викладачів та студентів (G. Gedvilienè, 2012), соціальні навички та навички командної роботи (E. Leganés-Lavall, S. Pérez-Aldeguer, 2016).

Проблемі формування та діагностики рівня соціальної компетентності присвячено чимало робіт сучасних українських науковців. Наприклад, Н.В. Борбич вивчала формування соціальної компетентності студентів педагогічних коледжів; Ю.В. Борець - соціальну компетентність як інтегральну характеристику розвитку особистості; І.Б. Зарубінська - формування соціальної компетентності особистості в студентському віці; I.I. Сидорук уважає, що оцінювання соціальної компетентності майбутніх соціальних працівників має грунтуватися на комплексному (трикомпонентному) результаті, який відображає взаємопов'язані складники; О.І. Гура, О.С. Грибанова, А.О. Деркач, О.А. Дубасенюк діагностували рівень професійної компетентності загалом та показник соціальної компетентності зокрема; В.П. Мушинський сформував діагностичний мінімум «Діагностика соціальної компетентності особистості».

Водночас недостатньо вивченим є питання діагностики соціальної компетентності молоді в діяльності громадських організацій.

Мета дослідження - розробити та обгрунтувати діагностичний інструментарій визначення рівня сформованості соціальної компетентності молоді в діяльності громадських організацій. 
Виклад основного матеріалу дослідження. Соціальна компетентність молоді - складне багатоаспектне особистісне утворення, що містить комплекс знань, умінь, навичок, мотивів та особистісних якостей, які забезпечують ефективну діяльність у громадських організаціях та в громаді загалом.

Пошук інструментів для визначення рівня сформованості соціальної компетентності молоді в діяльності громадських організацій залежить від тлумачення змісту соціальної компетентності та іiі структурних компонентів.

Аналізуючи наукову літературу, ми визначили, що є чимало визначень поняття «соціальна компетентність особистості». Це пов'язано 3 тим, що вона охоплює професійну, навчальну, громадську, особистісну сфери життєдіяльності людини; визначено різні показники та критерії формування соціальної компетентності. Крім того, соціальна компетентність молоді виконує важливу роль у міжособистісній взаємодії, що ми й будемо відстежувати в процесі залучення молоді до діяльності в громадських організаціях.

Серед базових компетентностей, які формуються у молоді, соціальна компетентність $€$ найважливішою для встановлення соціальних контактів, розуміння суті міжособистісної взаємодії, оскільки є основним функціональним інструментом ефективної діяльності.

I.I. Сидорук визначає соціальну компетентність як багатовимірну конструкцію 3 мотиваційними, когнітивними, особистісними, діяльнісними й контекстуальними вимірами, що містить взаємодію між індивідуальними характеристиками особистості, соціальними вимогами та особливостями культурного контексту й контексту предметної сфери професійної діяльності, а також взаємопов'язані складники (мотиваційно-ціннісний, когнітивно-діяльнісний, особистісно-рефлексивний) (Сидорук, 2021; Лякішева, 2021).

М.О. Докторович на основі системного підходу розробила і науково обгрунтувала таку структуру соціальної компетентності: когнітивно-ціннісний (наявність знань, соціальних уявлень, системи цінностей особистості, розуміння соціальної дійсності); емоційно-мотиваційний (характеризується емоційним ставленням до соціуму та мотивами діяльності); інтерактивно-комунікативний (передбачає здійснення продуктивної комунікації з індивідами та групами, виконання різних ролей комунікації); поведінково-діяльнісний (представлений рівнем ціннісного ставлення до соціуму через поведінку та діяльність) компоненти (Докторович, 2007).

T.М. Смагіна виділяє в структурі соціальної компетентності знаннєвий, ціннісний та поведінковий компоненти. До знаннєвого компонента вона уналежнює знання про правила комунікації; про суспільство та суспільні закони; про процеси прийняття суспільних рішень; про основи співпраці та спілкування 3 іншими та розв'язання конфліктних ситуацій. Ціннісний компонент передбачає здатність відчувати власну гідність, шанувати права людини, здатність до соціальної відповідальності тощо. Поведінковий компонент передбачає вміння визначати мету комунікації, застосовувати ефективні стратегії спілкування залежно від ситуації, брати на себе відповідальність тощо (Смагіна, 2010).

Ми вважаємо, що дослідження соціальної компетентності молоді в діяльності громадських організацій передбачало вивчення як окремих компонентів соціальної компетентності, так і їі загального показника. Тому в структурі соціальної компетентності молоді умовно можна виділити внутрішній та зовнішній складники. Такий поділ обгрунтований факторами впливу на формування та розвиток певних знань, умінь та навичок. Отже, соціальна компетентність формується під впливом як зовнішніх, так і внутрішніх процесів.

Внутрішній складник компетентності включає ставлення, емоції, цінності та етичні норми, мотивацію, громадську участь тощо, а зовнішній - соціальні та політичні зміни в суспільстві, фінансову ситуацію в країні, розвиток громадянського суспільства, діяльність громадських організацій, наявність необхідних умов для розвитку соціальної компетентності тощо (Карпук, 2021).

Аналіз запропонованих підходів дає нам підстави виокремити такі основні компоненти формування соціальної компетентності молоді:

1) мотиваційно-особистісний - відображає ставлення до суспільства, особистісну мотивацію участі в діяльності громадських організацій, мотиви саморозвитку та досягнення успіху, адекватну самооцінку, гнучкість, таймменеджмент, ініціативність, емоційну стійкість, емпатійність, прагнення до лідерства; 
2) когнітивно-ціннісний критерій характеризується здатністю відчувати власну гідність, поважати права людини, виявляти соціальну відповідальність, а також наявність життєвих орієнтацій і цілей, толерантність тощо;

3) комунікативний критерій передбачає комунікативність, емоційний інтелект, критичне мислення, застосовування ефективних стратегій спілкування залежно від ситуації, генерацію ідей тощо;

4) діяльнісний - навички командної роботи, використання сучасних технологій, креативність, медіаграмотність, цифрова грамотність, вияви громадянської участі та соціальної активності тощо.

Для діагностики рівня сформованості соціальної компетентності молоді науковці застосовують різні методики, спрямовані на оцінку сформованості компонентів і соціальної компетентності загалом: опитувальники, спеціальні тести, проєктивні методики, анкети, методи самооцінки, методи експертних оцінок, спостереження, бесіди, аналіз громадської активності, аналіз діяльності в молодіжних організаціях тощо.

Визначені нами компоненти формування соціальної компетентності молоді дозволили підібрати та обгрунтувати діагностичний інструментарій. Під час вибору методів діагностики сформованості рівня соціальної компетентності молоді потрібно враховувати вікові особливості молодих людей, доступність у використанні методик та обробці отриманих емпіричних даних; можливість комплексного застосування методик для одночасного оцінювання всіх складників компетентності та можливість проведення повторного зрізу (Сидорук, 2021; Лякішева, 2021).

Представимо методики та їх короткий опис, які варто використовувати в дослідженні рівня сформованості соціальної компетентності молоді в діяльності громадських організацій відповідно до визначених показників.

Методика «Вимірювання комунікативної й соціальної компетентності» КОСКОМ В. Куніциної. Має на меті визначити соціальну компетентність як складне багаторівневе психологічне утворення. Опитувальник містить 90 тверджень, які формують 15 шкал: розуміння ситуації; вправність, моральні настановлення, мотивацію досягнення успіху, емоційну стійкість, уміння самопрезентації, соціально- психологічну компетентність, вербальну компетентність, оперативну соціальну компетентність, его-компетентність, комунікативну компетентність, упевненість, стабільність людських стосунків, мотивацію схвалення (шкала брехні), комунікативно-особистісний потенціал (Сидорук, 2021; Лякішева, 2021).

Для визначення рівня критичного мислення можна використати «Адаптований тест критичного мислення» Л. Старкі (адаптований О.Л. Луценко). Тест містить 27 тверджень/ питань, кожне 3 яких має чотири варіанти вибору відповіді.

Завдяки тесту можна визначити рівень навичок критичного мислення (логіка, індукція i дедукція, здатність до критичного аналізу інформації, техніки переконання, відволікання уваги, здатність протистояти маніпуляціям, контроль над емоціями й усвідомленням їх впливу на прийняття рішень). Загалом, він може бути основою для формування рекомендацій щодо розвитку навичок критичного мислення (Луценко, 2014).

Опитувальник Ю.М. Орлова «Потреба в спілкуванні» (Бондарчук, 2010: 85). Потреба в спілкуванні $\epsilon$ однією 3 основних потреб людини. У їі основі лежить, по-перше, потреба в емоційному контакті; по-друге, пошук контактів і взаємодія із соціумом. Запропонована методика становить тест-опитувальник, який містить 33 твердження, 3 якими респондент погоджується або ні, на основі чого можна дослідити високий або низький рівень потреби в спілкуванні.

Методика «Тест емоційного інтелекту EQ» (Н. Холл) слугує для виявлення здібності особистості розуміти відносини, представлені в емоціях, і керувати своєю емоційною сферою на основі прийняття рішень. Вона складається з 30 тверджень і містить п'ять шкал, як-от емоційна обізнаність, управління емоціями, самомотивація, емпатія, розпізнавання емоцій інших людей (Яцюк, 2019).

Опитувальник М. Шерер та Дж. Маддукс «Шкала самоефективності», адаптований А.В. Бояринцевою (Бондарчук, 2010: 80). Це одна 3 методик дослідження самооцінки особистості своєї самореалізації, самоефективності, тобто можливість людини виявити свої здібності та використовувати їх найкращим чином. 
Опитувальник складається 3 трьох шкал, як-от загальна, діяльнісна, соціальна самоефективність особистості, та визначає оцінку людиною свого потенціалу, яким вона реально може скористатися. Респондентам пропонують 23 твердження, які потрібно оцінити від 1 до 10 (1 - абсолютно не згоден, 10 - повністю згоден). При цьому особливого значення надається тому, що вміле використання здібностей дозволяє людині досягти високих результатів.

Методика «Діагностика особистісної креативності» (Є.Є. Тунік) дозволяє визначити чотири особливості творчої особистості: допитливість (Д); уяву (У); складність (С) і схильність до ризику (Р). Опитувальник містить 50 тверджень та розроблений для того, щоб оцінити, якою мірою респонденти $є$ здатними на ризик, допитливими, володіють уявою та віддають перевагу складним ідеям (Туник, 2003).

Опитувальник А. Реана «Мотивація успіху та страх невдачі» (Фетискин, 2009). Методика складається 320 запитань, на кожне з яких необхідно дати позитивну або негативну відповідь. Провідною функцією мотиву досягнення $€$ спонукання особистості до досягнення успіху в діяльності, а мотиву уникнення невдач у запобіганні неуспіху, поразки. У результаті дослідження російського ученого А. Реана встановлено, що мотивація досягнення успіху має позитивний характер. У такій мотивації дії працівника спрямовуються на те, щоб досягти значних позитивних результатів.

Опитувальник дасть змогу визначити, наскільки респонденти мотивовані на успіх чи невдачу, сподіваються на успіх чи присутній страх невдачі. Таким чином, можна побачити, наскільки молоді люди впевнені в собі, своїх силах, відповідальні, ініціативні та активні.

Методика «Діагностика оцінки самоконтролю в спілкуванні». Ця діагностика розроблена американським психологом Марком
Снайдером і призначена для діагностики рівня комунікативного контролю. Респондентам пропонуються 10 речень, які описують реакції на певні ситуації і кожне з яких потрібно оцінити як правильне чи неправильне залежно від своєї реакції (Бондарчук, 2010).

Така методика має розподіл рівнів комунікативного контролю на низький, середній та високий.

Методика «Діагностика рівня емпатії» I.M. Юсупова. Опитувальник включає 6 діагностичних шкал емпатії, що виражають рівень емпатійних тенденцій до батьків, тварин, людей похилого віку, дітей, героїв художніх творів, знайомих і незнайомих людей. Опитувальник містить 36 тверджень, кожне 3 яких слід оцінити так: «не знаю» (0), «ні, ніколи» (1), «інколи» (2), «часто» (3), «майже завжди» (4), «так, завжди» (5)». Це дозволяє визначити рівень емпатійності: дуже високий рівень, висока емпатійність, нормальний рівень емпатійності, низький рівень емпатійності, дуже низький рівень (Бондарчук, 2010: 82).

Висновки і перспективи подальших досліджень. Ефективність діяльності молоді в громадських організаціях залежить від рівня сформованості їх соціальної компетентності, яка трактується як багатоаспектне особистісне утворення, що містить комплекс знань, умінь, навичок, мотивів та особистісних якостей. Обгрунтування комплексу діагностичних методик дослідження рівня соціальної компетентності молоді в громадських організаціях залежить від тлумачення змісту соціальної компетентності та ii структурних компонентів, виокремлених нами: мотиваційно-особистісного, когнітивноціннісного, комунікативного, діяльнісного.

Подальше дослідження буде спрямоване на емпіричне вивчення рівня соціальної компетентності молоді в діяльності громадських організацій за обгрунтованим інструментарієм.

\section{ЛІТЕРАТУРА:}

1. “The Future of Jobs Report”. URL: http://www3.weforum.org/docs/WEF_Future_of_Jobs_2020.pdf (дата звернення: 20.10.2021).

2. Докторович М.О. Формування соціальної компетентності старшого підлітка 3 неповної сім’ї : автореф. дис. ... кандидата пед. наук : 13.00.05. Київ. 2007. 20 с.

3. Карпук В. Структурні аспекти соціальної компетентності молоді. Соціальна робота: виклики сьогодення: зб. наук. пр. за матеріалами Х Міжн. наук.-практ. конф., м. Тернопіль, 13-14 травня 2021 p. Тернопіль, 2021. С. 215-219. 
4. Луценко Е.Л. Адаптация теста критического мышления. Вісник Харківського національного університету імені В.Н. Каразіна. Серія : Психологія. 2014. № 1110. С. 65-70. URL: http://nbuv.gov.ua/UJRN/ VKhIPC_2014_1110_55_14

5. Методика дослідження особливостей психологічної готовності керівників освітніх організацій до діяльності в умовах змін / за наук. ред. О. І. Бондарчук. Київ : ДВНЗ «Університет менеджменту освіти» НАПН України, 2014. 148 с.

6. Сидорук І., Лякішева А. Діагностичний інструментарій для визначення стану сформованості соціальної компетентності майбутніх соціальних працівників. Humanitas. 2021, 2. С. 51-57, doi: https://doi.org/10.32782/ humanitas/2021.2.8

7. Смагіна T.М. Поняття та структура соціальної компетентності учнів як наукова проблема. Вісник Житомирського державного університету. Педагогічні науки. 2010. Вип. 50. С. 138-142.

8. Туник Е.Е. Модифицированные креативные тесты Вильямса. Санкт-Петербург : Речь, 2003. 96 с.

9. Фетискин Н.П. Социально-психологическая диагностика развития личности и малых групп. Москва : Психотерапия, 2009. 544 с.

10. Яцюк М. Емоційний інтелект особистості (на хвилі Нової української школи) : навч.-метод. посіб. Вінниця : Діло, 2019. 105 с.

\section{REFERENCES:}

1. «The Future of Jobs Report». Retrieved from http://www3.weforum.org/docs/WEF_Future_of_Jobs_2020.pdf

2. Bondarchuk O. I. (2014). Metodyka doslidzhennya osoblyvostey psykholohichnoyi hotovnosti kerivnykiv osvitnikh orhanizatsiy do diyalnosti $v$ umovakh zmin [Methods of research of features of psychological readiness of heads of the educational organizations to activity in the conditions of changes]. Kyiv: DVNZ «Universytet menedzhmentu osvity» NAPN Ukrayiny [in Ukrainian].

3. Doktorovych M. O. (2007). Formuvannya sotsialnoyi kompetentnosti starshoho pidlitka z nepovnoyi simyi [Formation of social competence of the senior teenager from a single-parent family]. Kyiv [in Ukrainian].

4. Fetiskin N.P. (2009). Sotsialno-psikhologicheskaya diagnostika razvitiya lichnosti i malykh grupp [Sociopsychological diagnosis of personality development and small groups]. Moskva: Psikhoterapiya [in Russian].

5. Karpuk V. (2021). Strukturni aspekty sotsialnoyi kompetentnosti molodi [Structural aspects of social competence of youth]. Sotsialna robota: vyklyky sohodennya: X Mizhnarodnoyi naukovo-praktychnoyi konferentsiyi - Social work: challenges of today: The Tenth International Scientific and Practical Conference. Ternopil [in Ukrainian].

6. Lutsenko E. L. (2014). Adaptatsiya testu krytychnoho myslennya [Adaptation of the critical thinking test]. Visnyk Kharkivs'koho natsional'noho universytetu imeni V. N. Karazina, 1110, 51-57. Retrieved from http://nbuv.gov.ua/UJRN/ VKhIPC_2014_1110_55_14 [in Russian].

7. Smahina T. M. (2010). Ponyattya ta struktura sotsialnoyi kompetentnosti uchniv yak naukova problema [The concept and structure of social competence of students as a scientific problem]. Visnyk Zhytomyrskoho derzhavnoho universytetu. Pedahohichni nauky, 50, $138-142$ [in Ukrainian].

8. Sydoruk, I. \& Liakisheva, A. (2021) Diahnostychnyi instrumentarii dlia vyznachennia stanu sformovanosti sotsialnoi kompetentnosti maibutnikh sotsialnykh pratsivnykiv [Diagnostic Tools for Assessing the State of the Social Competence Formation of Future Social Workers]. Humanitas, 2, 51-57, doi: https://doi.org/10.32782/humanitas/2021.2.8

9. Tunik Ye.Ye. (2003). Modifitsirovannyye kreativnyye testy Vilyamsa [Modified Williams creative tests]. SanktPeterburg: Rech [in Russian].

10. Yatsyuk M. (2019). Emotsiynyy intelekt osobystosti (na khvyli Novoyi ukrayinskoyi shkoly) [Emotional intelligence of the individual (on the wave of the New Ukrainian school)]. Vinnytsya: Dilo [in Ukrainian]. 